\title{
60 YEARS OF POMC POMC: the consummate peptide hormone precursor
}

\author{
Adrian J L Clark ${ }^{1}$ and Philip Lowry² \\ ${ }^{1}$ Centre for Endocrinology, William Harvey Research Institute, Queen Mary University of London, \\ London, UK \\ 2Emeritus Professor School of Biological Sciences, The University of Reading, Reading, UK
}

Correspondence should be addressed to A J L Clark or P Lowry Email

a.j.clark@qmul.ac.uk or p.j.lowry@reading.ac.uk
Proopiomelanocortin (POMC) has been at the forefront of molecular endocrinology for the past 60 years, and the concepts derived from POMC research have led the way in understanding a wide range of endocrine systems. In this issue, we celebrate this enormous body of work with contributions from an outstanding faculty of contributors, many of whom have led these discoveries. The story begins approximately 60 years ago when Li and colleagues reported purifying and sequencing ACTH (Li et al. 1955, Dixon \& Li 1956). They and others subsequently reported purification of $\alpha$ - and $\beta$-MSH; however, it was with the discovery of $\beta$-LPH that the prohormone theory was advanced: that a single peptide precursor molecule could contain several independent biologically active members. These discoveries, and his contributions to them, are reviewed by Phil Lowry (Lowry 2016). A key discovery was that of $\beta$-endorphin: Derek Smyth recalls his work and the events surrounding this (Smyth 2016).

Confirmation of the single-precursor concept was provided by the cloning of the POMC gene by Nakanishi and coworkers; work reviewed by Adrian Clark (Clark 2016). Cloning of POMC additionally revealed undiscovered N-terminal components of this precursor whose potential biological function is reviewed by Andrew Bicknell (Bicknell 2016).

Understanding the processing of these peptides has provided fundamental models that are observed extensively in peptide biology. Specifically, cleavage of POMC into its active components requires the action of a novel series of enzymes, the prohormone convertases, reviewed by Michel Chretien and Majambu Mbikay (Chretien \& Mbikay 2016). Further processing of POMC products by C-terminal amidation revealed the class of peptidylglycine $\alpha$-amidating monooxygenase enzymes whose far wider role continues to be an active area of research and is reviewed by Dhivya Kumar and colleagues (Kumar et al. 2016). The subsequent trafficking, sorting, and storage of POMC products before secretion has also contributed significantly to our knowledge of the broader aspects of this process and is reviewed by Peng Loh and colleagues (Cawley et al. 2016).

Cloning of the POMC gene confirmed the highly tissue-specific nature of its expression and simultaneously revealed the nature of its promoter. This enabled investigation into the factors controlling these characteristics, and this fascinating work is discussed by Jacques Drouin, whose lab has led the way in this area (Drouin 2016). Access to POMC sequences across a wide variety of species has permitted a fascinating understanding of the evolution of this and related genes and is reviewed by Cerdá-Reverter and colleagues (Navarro et al. 2016). Equally fascinating is the evolution of the receptors for the melanocortin peptides derived from POMC, and this topic is considered in depth by Robert Dores and colleagues (Dores et al. 2016).

The biological actions of ACTH originally led to the interest in purifying POMC, and those actions of ACTH continue to fascinate. This complex subject is expertly reviewed by Nicole Gallo-Payet (Gallo-Payet 2016). More recently, the enormous role of POMC-derived MSH peptides in the regulation of appetite and food intake has been recognised, and we are fortunate to conclude this collection with an outstanding article from Roger Cone, one of the major contributors in this area (Anderson et al. 2016).

These articles reveal several areas in which our understanding is deficient. Individual authors have 
highlighted many of these; however, four of those that strike us as important are the following:

1. Although lipotrophin was the first indication of the existence of the POMC precursor and was isolated by virtue of its lipolytic activity, little more has been revealed from this feature of its biochemistry. Even the possibility of an opiate peptide $\beta$-endorphin being generated from $\beta-\mathrm{LPH}$ is a moot point in the pituitary gland, given that when there is a functioning pars intermedia, it is acetylated at its $\mathrm{N}$-terminal (as with $\alpha$ MSH), which effectively destroys its opiate activity. Are there unrecognised functions of this peptide?

2. The conservation during evolution of the structure of the N-terminal region of POMC has certainly added credibility to the importance of this part of the precursor, and yet our full understanding of the mechanism by which all the relevant biological activity is expressed has still not been resolved. Here, in particular, the molecular form of each peptide would appear to be of vital importance, and we would encourage future workers in this area to use the natural peptides or the ones in which the synthesis has been designed to ensure the correct alignment of disulphide bridges.

3. The identity of the natural POMC agonist for the MC3R would be of great interest. The fact that in teleosts the absence of a MC3R appears to coincide with the loss of conservation of the $\gamma$-MSH sequence would suggest that at least $\gamma$-MSH forms part of its natural agonist.

4. Despite the bovine pars intermedia being the source of the RNA for the cloning of POMC and the plethora of POMC peptides it expresses, this part of the pituitary gland is still looking for a function in mammals.

Ultimately, we hope that the articles in this issue will inspire the next generation of molecular endocrinologists to answer these and other questions. POMC has played an extraordinary role in the development of molecular endocrinology and has clearly not yet given up all its secrets.

\section{Declaration of interest}

The authors declare that there is no conflict of interest that could be perceived as prejudicing the impartiality of this editorial.

\section{Funding}

This work did not receive any specific grant from any funding agency in the public, commercial or not-for-profit sector.

\section{References}

Anderson EJP, Çakir I, Carrington S, Cone RD, GhamariLangroudi M, Gillyard T, Gimenez LE \& Litt M 201660 YEARS OF POMC: Regulation of feeding and energy homeostasis by aMSH. Journal of Molecular Endocrinology 56 T157-T174. (doi:10.1530/JME-16-0014)

Bicknell AB 201660 YEARS OF POMC: N-terminal POMC peptides and adrenal growth. Journal of Molecular Endocrinology 56 T39-T48. (doi:10.1530/JME-15-0269)

Cawley NX, Li Z \& Loh YP 201660 YEARS OF POMC: Biosynthesis, trafficking and secretion of proopiomelanocortin-derived peptides. Journal of Molecular Endocrinology 56 T77-T97. (doi:10.1530/JME-150323)

Chretien M \& Mbikay M 201660 YEARS OF POMC: From the prohormone theory to proopiomelanocortin and to proprotein convertases (PCSK1 to PCSK9). Journal of Molecular Endocrinology 56 T49-T62. (doi:10.1530/JME-15-0261)

Clark AJL 201660 YEARS OF POMC: The proopiomelanocortin gene: discovery, deletion and disease. Journal of Molecular Endocrinology $\mathbf{5 6}$ T27-T37. (doi:10.1530/JME-15-0268)

Dixon JS \& Li CH 1956 Isolation and properties of corticotropin from bovine pituitary glands. Science 124 934. (doi:10.1126/ science.124.3228.934)

Dores RM, Liang L, Davis P, Thomas AL \& Petko B 201660 YEARS OF POMC: Melanocortin receptors: evolution of ligand selectivity for melanocortin peptides. Journal of Molecular Endocrinology 56 T119-T133. (doi:10.1530/JME-15-0292)

Drouin J 201660 YEARS OF POMC: Transcriptional and epigenetic regulation of POMC gene expression. Journal of Molecular Endocrinology 56 T99-T112. (doi:10.1530/JME-15-0289)

Gallo-Payet N 201660 YEARS OF POMC: Adrenal and extra-adrenal functions of ACTH. Journal of Molecular Endocrinology 56 T135-T156. (doi:10.1530/JME-15-0257)

Kumar D, Mains RE \& Eipper E 201660 YEARS OF POMC: From POMC and $\alpha \mathrm{MSH}$ to PAM, molecular oxygen, copper and vitamin C. Journal of Molecular Endocrinology 56 T63-T76. (doi:10.1530/JME-150266)

Li CH, Geschwind II, Cole RD, Raacke ID, Harris JI \& Dixon JS 1955 Amino-acid sequence of alpha-corticotropin. Nature 176 687-689. (doi:10.1038/176687a0)

Lowry P 201660 YEARS OF POMC: Purification and biological characterisation of melanotrophins and corticotrophins. Journal of Molecular Endocrinology 56 T1-T12. (doi:10.1530/JME-15-0260)

Navarro S, Soletto L, Puchol S, Rotllant J, Soengas JL \& CerdáReverter JM 201660 YEARS OF POMC: An evolutionary perspective. Journal of Molecular Endocrinology 56 T113-T118. (doi:10.1530/JME15-0288)

Smyth D 201660 YEARS OF POMC: Lipotropin and beta-endorphin: a perspective. Journal of Molecular Endocrinology 56 T13-T25. (doi:10.1530/JME-16-0022)

Received in final form 25 January 2016

Accepted 28 January 2016 http://jme.endocrinology-journals.org DOI: 10.1530/JME-16-0016
๑ 2016 Society for Endocrinology Printed in Great Britain
Published by Bioscientifica Ltd 